\title{
INFLUENCE OF WHEELED TYPES OF A Skidder ON PRODUCTIVITY AND COST OF THE FOREST HARVESTING
}

\author{
Eduardo da Silva Lopes ${ }^{1}$, Diego de Oliveira $^{2}$, Jean Alberto Sampietro ${ }^{3}$ \\ ${ }^{1}$ Forest Eng., Dr., Forest Engineering Department, UNICENTRO, Irati, PR, Brazil - eslopes@ pq.cnpq.br \\ ${ }^{2}$ Forest Eng., Master in Forestry Sciences, UNICENTRO, Irati, PR, Brazil - diegotst2007@yahoo.com.br \\ ${ }^{3}$ Forest Eng., Dr., Forest Engineering Department, UDESC, Lages, SC, Brazil - engsampietro@ hotmail.com
}

Received for publication: 01/04/2013 - Accepted for publication: 31/10/2013

\begin{abstract}
The objective of this study was to evaluate the influence of different wheel types of a skidder on productivity and cost of Pinus taeda L. wood extraction. The study was conducted in a forestry company located in the municipality of Mandirituba, Paraná state, Brazil. The technical and cost analyses included a time and motion study of the wood extraction activity. The productivity, operative efficiency, energy consumption and the production and operational costs were determined for the machines with different wheel types: SDP - skidder with rubber tires; SD2 - skidder with tracks on the two front tires; and SD4 skidder with tracks on the four tires. Results showed that the activity that demanded most time in the operational cycle was the maneuvering of the machines to pick up more than one tree, resulting in lost of productivity and need of improvement in the operational planning. The skidder equipped only with rubber tires showed higher productivity and lower production cost in the longest extraction distances, caused by the higher operating speed of the machine.
\end{abstract}

Keywords: Timber extraction; wheel types; operating efficiency.

\section{Resumo}

Influência dos rodados de um skidder na produtividade e no custo da extração florestal. Este trabalho objetivou avaliar a influência de diferentes tipos de rodados de um skidder na produtividade e no custo da extração de madeira de Pinus taeda L. O estudo foi conduzido em uma empresa florestal localizada no município de Mandirituba, estado do Paraná, Brasil. As análises técnica e de custo englobaram um estudo de tempos e movimentos da operação de extração florestal. Foi determinado a produtividade, eficiência operacional, rendimento energético e custos operacionais e de produção das máquinas equipadas com diferentes tipos de rodados: SDP - skidder com rodados de pneus; SD2 skidder com pneus dianteiros recobertos com semiesteiras e SD4 - skidder com os quatro pneus recobertos com semiesteiras. Os resultados mostraram que a atividade que demandou o maior tempo do ciclo operacional foram as manobras realizadas pelas máquinas para apanhar mais de uma árvore, ocasionando perda de produtividade e necessidade de melhoria no planejamento operacional. O skidder equipado somente com rodados de pneus apresentou maior produtividade e menor custo de produção nas maiores distâncias de extração, ocasionado pela maior velocidade operacional da máquina.

Palavras-chave: Extração florestal; tipos de rodados; eficiência operacional.

\section{INTRODUCTION}

Wood harvesting and transportation are considered among the most important activities in economic terms, representing 50\% or more of the final wood production cost (MACHADO, 2008). Furthermore, these two steps are influenced by various technical, economical, environmental and ergonomic factors that have direct influence on operational modes and on production costs (LOPES et al., 2011).

According to Bramucci and Seixas (2002), starting from the nineties there was an intense mechanization in the wood harvesting, caused by the need of a greater availability of raw material, high labor costs, necessity to improve working conditions and, mainly, by the need to reduce production costs. For those reasons, the improvement of forestry techniques and operations, together with the knowledge of machines productivity and costs under different conditions, become very important for their contribution 
to the improvement of the operational planning, increase of productivity and reduction of the production costs (MINETTE et al., 2004).

Wood extraction is referred the movement of trunks from the inside to the borders of forest plot, to the carrier or intermediate deposit, and it is an highly expensive step that needs an efficient planning in terms of tree felling directions, drag capability, dispositions of wood bundles, conditions of the carrier and supporting capability of the soils, among others (SEIXAS, 2008).

Oliveira et al. (2009) affirm also that the experience of operators, forest conditions, terrain characteristics, distance of the skidding, type of machines and wheels are among the factors that have influence on forest harvesting and must be considered when defining the operational plan.

Among the machines used in forest harvesting, the skidder is mentioned, which is an articulated tractor used for skidding complete trees or trunks. Wheels may be rubber tires, semi-tracked tires or full tracked tires. It is a machine with high power and productivity, however it can cause very damages to the environment, mainly in terms of soil compaction (HENDRISON, 1990; WARKOTSCH; OLSEN, 1992).

Nowadays, when wood extraction is conducted under humid soil conditions and steep slopes, skidding of machines is very common when they are equipped with rubber tires only, due to the lower tire-soil grip conditions. This situation may cause an increase of the operational cycle time and subsequently a loss of productivity; increase of production costs and soil compaction may also result (BYGDÉN et al., 2003 e LOPES et al., 2007).

For those reasons many forestry companies use machines with tracks on tires, mainly when wood extraction is carried out under humid and steep slope soil conditions, because tracks will contribute to a bigger traction capability and operating efficiency of the machine, and also contribute to reduction of disturbances caused to the soil.

It is thus clear the need for studies to show the effects of machines with different types of wheels on productivity and operating costs of the timber extraction, since this is and highly expensive and complex operation with a potential to be causing soil compaction.

The aim of this work was to evaluate the influence of the different types of wheels on skidder productivity and extraction costs of Pinus taeda L, giving support to forestry operations planning.

\section{MATERIAL AND METHODS}

\section{Studied area}

The study was conducted in the operational areas of a forestry company in the Mandirituba, Parana Stare, Brazil, located between $25^{\circ} 46^{\prime} 44^{\prime \prime}$ S and 49 $19^{\prime} 30^{\prime \prime}$ W parallels.

The characteristic climate of the region is humid subtropical mesothermal or Cfb (Köppen), with annual average rainfall of $1,400 \mathrm{~mm}$, annual average temperature of $22{ }^{\circ} \mathrm{C}$ and average altitude of $840 \mathrm{~m}$.

Starting from soil samples collected in field and analyzed in laboratory, following the methodology proposed by EMBRAPA (1997). The soil of the studied area was classified as Red-Yellow Dystrophic Latosol (Lbd). Texture was classified as clayey with $449.0,255.0$ and 296.0 g.kg ${ }^{-1}$ of clay, silt and sand, respectively. Gravimetric humidity was found $0.418,0.395$ and $0.381 \mathrm{~kg} \cdot \mathrm{kg}^{-1}$ and organic carbon content was $12.8,8.8$ e 7.1 dag.kg ${ }^{-1}$ respectively, in the layers from 0 to 15,15 to 30 and 30 to $50 \mathrm{~cm}$ deep.

Data were collected in Pinus taeda L. stands, topography was slightly undulating with an average slope gradient of $4.5^{\circ}$, average trees volume of $1,58 \mathrm{~m}^{3}$ at the age of 35 years and in clear cut regime.

\section{Wood harvesting system}

The harvesting system adopted by the forestry company was the Full Tree system, with felling, extraction and processing operations performed through mechanized methods. Felling and stacking of the trees in bundles inside the stand were conducted using a feller-buncher forest tractor, followed by dragging of the bundles to the border of the stand using a skidder forest tractor, and finally, processing of the trees into different assortments at the border of the stand was performed with an Harvester forest tractor.

Objective of this research was to study the skidder, made by Caterpillar, model 545, with $4 \times 4$ traction, nominal power of $225 \mathrm{hp}$, wheeled with tires, claw area of $1.5 \mathrm{~m}^{2}$ and operational weight of 18.2 tons. Timber extraction operation was analyzed with the described machine equipped with different types of tires: SDP - skidder with rubber tires; SD2 - skidder with front wheels equipped with tracks and SD4 - 
skidder with all four tires equipped with tracks. The accessory type was Eco Wheel Track, made by Olofsfors (Figure 1).

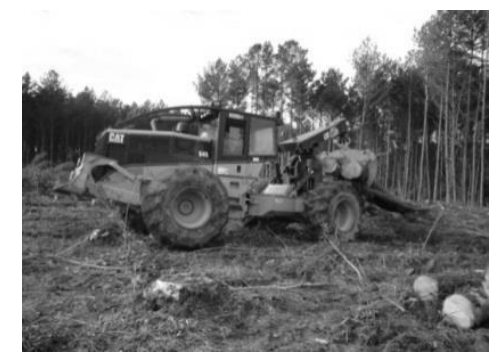

(a)

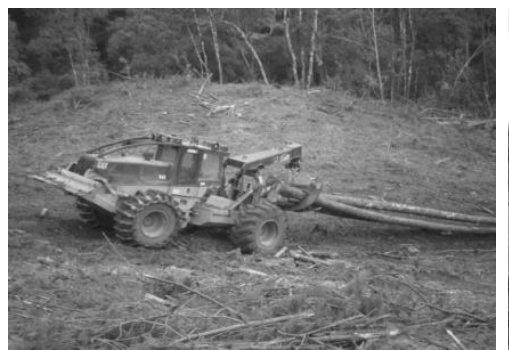

(b)

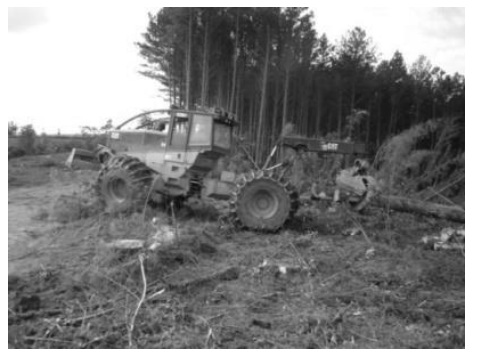

(c)

Figure 1. Skidder with rubber tires (a), front tires equipped with tracks (b) all tires equipped with tracks (c).

Figura 1. Skidder com pneus (a), com dois pneus dianteiros recobertos com semi-esteiras (b) e com os quatro pneus recobertos com semi-esteiras (c)

\section{Sampling procedure}

Three operators were used in the study, selected basing on information given by the forestry company, all of them with experience in the extraction operation with the skidder and with similar productivity levels each other.

At first a pilot study was conducted on machines during timber extraction, with the intent to define the number of sample observation (operational cycle) needed to guarantee a maximum sample error of 5\%, according to the methodology proposed by Barnes (1977), through the following expression:

$$
n \geq \frac{t^{2}+C V^{2}}{E^{2}}
$$

Where: $\mathrm{n}=$ minimum number of operative cycles needed;

$\mathrm{t}=$ value of $\mathrm{t}$, for the level of confidence desired and (n-1) degrees of freedom;

$\mathrm{CV}=$ coefficient of variation, in percentage and;

$\mathrm{E}=$ acceptable error, in percentage.

\section{Technical analysis}

Technical analysis of the skidder, wheeled with different types of tires was based on a time and motion study, in order to analyze the operational cycle of the timber extraction phase and to determine its productivity, operational efficiency, energy performance together with operational and production costs.

The time and motion study was performed by the continuous times method, characterized by the measure of times without stop the chronometer, according to the methodology described by Barnes (1977). A centesimal chronometer, a measuring tape, specific stakes and worksheets were used.

The extraction operational cycle was divided into the following partial activities: Empty Trip (VV), including the trip of the machine from the borders of the stand to the inside, close to the wood bundles to be dragged; Maneuver and Loading (MC), movements performed by the machines and loading of the bundles of timber; Loaded Trip (VC), the trip of the machine from the inside of the stand to its border, dragging the bundles; Maneuver and Unload (MD), unloading of wood bundles and movements at the border of the stand; and Operational and Non-Operational Interruptions (INT).

Productivity of the skidder was determined through the average individual volume of the trees with bark, supplied by the company inventory, which value was multiplied by the number of trees extracted in the different operational cycles and then divided by the hours effectively worked, as per the following expression: 
Where: $\mathrm{PR}=$ productivity $\left(\mathrm{m}^{3} \mathrm{cc} \mathrm{he} \mathrm{e}^{-1}\right)$;

$$
P R=\frac{n \times V}{H e}
$$

$\mathrm{n}=$ number of extracted trees;

$\mathrm{V}=$ average individual volume of trees with bark $\left(\mathrm{m}^{3} \mathrm{cc}\right)$;

$\mathrm{He}=$ effective working time (hours).

Operational efficiency is the percentage of the effectively worked time towards the total time programmed for the operation, determined by the following expression

$$
E O=\frac{T E}{(T E+T I)} * 100
$$

Where: $\mathrm{EO}=$ operational efficiency $(\%)$;

$\mathrm{TE}=$ effective working time (hours);

$\mathrm{TI}=$ interruptions time (hours).

Energy efficiency indicates the mass of fuel needed to produce one unity of power in the time unit, obtained from the ratio between the effective specific fuel consumption in grams per kilowatt produced in one hour $\left(\mathrm{g} \cdot \mathrm{kW}^{-1} \mathrm{he}^{-1}\right)$ and the mean productivity, with bark, of the machine $\left(\mathrm{m}^{3} \mathrm{cc} \mathrm{h} \mathrm{h}^{-1}\right)$, expressed in $\mathrm{g} . \mathrm{kW}^{-1} \mathrm{~m}^{3} \mathrm{cc}$ (OLIVEIRA et al., 2009).

\section{Economical analysis}

The economical analysis of the skidder with different wheel types was based on determination of the operational and production costs. Operational cost was determined through the accounting method, according to the methodology proposed by Miyata (1980) and Lopes (2001), with estimated values in reais $(\mathrm{R} \$)$. Information for the calculation were obtained by data collection on field and cost spreadsheet obtained from the company. Operational cost included: fixed costs (depreciation, interests and insurances), variable costs (fuel, lubricants and greases, hydraulic oil, tires, maintenance and repairs and transportation of workers), costs of personnel (salary and social charges) and administrative cost.

Production cost was obtained by dividing the operational costs $\left(\mathrm{R} \$ \mathrm{~h}^{-1}\right)$ by the productivity of the effective worked hour $\left(\mathrm{m}^{3} \mathrm{cc} \mathrm{he} \mathrm{e}^{-1}\right)$, corrected by the extraction operational efficiency index.

\section{Statistical analysis}

In this study a completely randomized experimental design (CRD) was applied, defining the following treatments: SDP, SD2 and SD4, being the replications defined as the number of operational cycles obtained in the pilot study. The distances of extraction (DE) were established in three classes: DE I $(\mathrm{DE}<50 \mathrm{~m})$; DE II $(50 \leq \mathrm{DE}<100 \mathrm{~m})$; and DE III $(100 \leq \mathrm{DE}<150 \mathrm{~m})$.

Productivity, production cost and energy efficiency of the skidder with different types of wheels in the different distances of extraction were compared. In the beginning, values were submitted to the test of Bartlett to verify homogeneity of variances and submitted to ANOVA, being the means compared by the Tukey test at $5 \%$ level of error probability.

Simultaneously, multiple stepwise regression models (MRMS) were adjusted to estimate the productivity (PROD) for each type of wheels, using Distance of Extraction (DE) and Extracted Volume per Operational Cycle (VOL) and independent variables. A General Regression Linear model (GLM) for PROD was also adjusted, keeping Distance of Extraction (DE) and extracted volume per operational cycle (VOL) as independent variables, and adding the "dummy" variable type of Wheels (ROD)

The adjusted equations were statistically evaluated through the adjusted determination coefficient ( $\mathrm{R}^{2}$ aj) (DRAPER; SMITH, 1981), standard absolute estimate error and percentage error (Syx e Syx \%) and the value of F. In the end, for each type of wheels studied, the mean values of PROD observed in the field and estimated through the regression models were compared with the Tukey range test, at $5 \%$ level of error probability. 


\section{RESULTS AND DISCUSSION}

\section{Time and motion study}

In the time and motion study, a total of 1,193 operational cycles of wood extraction operations were analyzed, being 370, 328 and 495 cycles respectively conducted with SDP, SD2 and SD4, being the obtained values more than the necessary for a sampling admissible error of 5\% at $95 \%$ of probability.

Figure 2 presents the mean percentage distribution of the activities that were included in the effective operational cycle of the skidder, with the different types of wheels. As it is observable, the partial activity that took most time was maneuver and loading, with $31.4 ; 35.5$ and $31.5 \%$ of the total time for SDP, SD2 and SD4, respectively. This result was similar to what obtained by other authors (FERNANDES et al., 2009; LOPES et al., 2007), who identified maneuver and loading as the most representative element of the operational cycle.

It is important to underline that, the long time for maneuver and loading is not a situation that should normally happen in the timber extraction with skidder, because as opposite to the forwarder, which passes most of its cycle in a passive mode, conducting the loadings and unloading (SEIXAS, 2008), the former should occupy most of the time in an active mode, in other words performing empty and loaded travels, and subsequently consuming less proportional time of the cycle in loading and unloading operations.

The long time consumed by the skidder with different types of wheels in the maneuver and loading was mainly due to the machine need to performed additional maneuver to pick a bigger number of trees, in order to optimize the load capability of the claw. However this situation happened due to the big individual volume of the trees and to the bigger spacing of the stand, that contributed to the formation of bundles in a more spaced configuration inside the compartment, each with a lower volume than the load capability of the skidder.

Therefore, the result showed the necessity of improvements in the operational planning of the extraction, being recommended that when the feller Buncher performs the felling, it should conduct some additional dragging, to group together a bigger number of trees per bundle and with compatible volume to the claw of the skidder. That recommendation is due to the fact that it is the most viable in this forest conditions, loss of time during tree felling compared to the time for extraction, that is the most complex and costly steps of all.
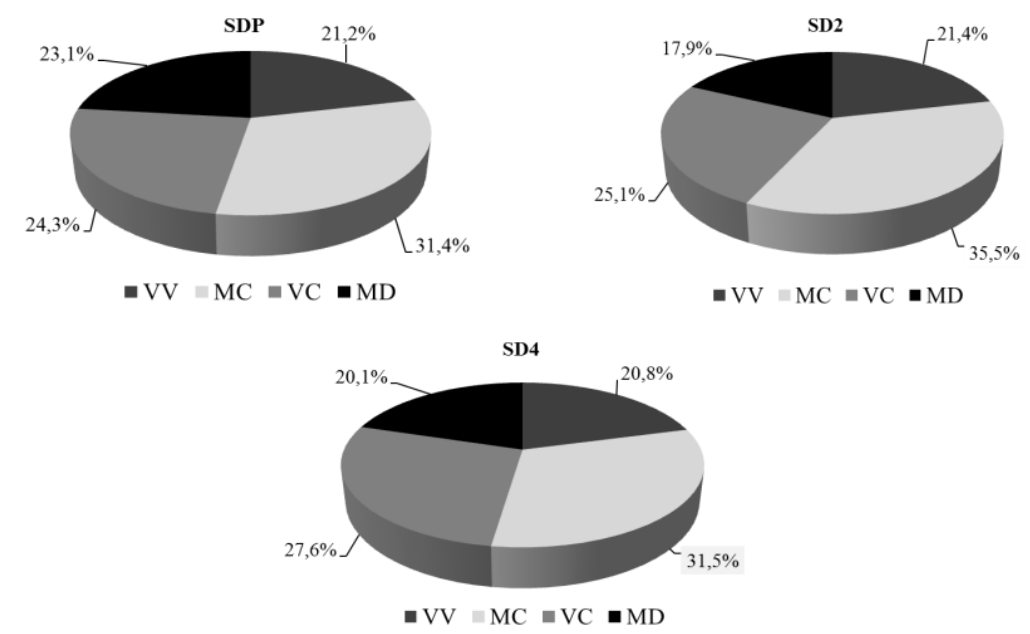

VV: Empty Trip; MC: Maneuver and Loading (MC); VC: Loaded Trip; MD: Maneuver and Unloading; INT: Operational and nonoperational interruptions; SD4: skidder with the four wheels equipped with tracks; SD2: skidder with front wheels equipped with tracks; SDP: skidder with rubber wheels.

Figure 2. Percentage composition of the operational cycle of the skidder with different types of wheels. Figura 2. Composição percentual do ciclo operacional do skidder com os diferentes tipos de rodados.

Analyzing the influence of the different types of wheels on the trip time of the skidder, it was verified that, for SD4, the partial activities empty trip (20.8\%) and loaded trip (20.7\%) took together $48.4 \%$ of the operational cycle total time, while for SDP the total time was $45.5 \%$, with this difference 
being possibly due to the higher mobility and operating speed developed by the machine when equipped only with rubber wheels, mainly in the longest extraction distances.

It is important also to highlight the fact that SD2 had the lowest empty and loaded trips time, with a mean gain of $12.5 \%$ compared to SD4. This result showed that the installation of tracks only in the front wheels may be an intermediary solution in terms of costs and productivity, allowing the machine a bigger mobility under adverse conditions (humid soils, with low support capability and steep slopes) and an increased dragging capability, increasing the operational efficiency as a consequence.

Finally, it has to be mentioned the high operational interruptions time of machines equipped with the various wheels types, caused by preventive and corrective maintenance, displacements between the stands and refueling performed during the working turn, which caused a mean operational efficiency of $61.6 \%$, considered lower than the recommended by Machado (1989), who suggests values above $70 \%$.

\section{Productivity, operational efficiency and energy efficiency}

In table 1 are reported the mean values of productivity and energy efficiency of the skidder with different equipments on wheels.

Productivity of the machine with all the types of wheels decreased significantly with the increase of the Distance of Extraction (DE), due to the increased time spent to complete the operational cycle, with consequent increase of the energy efficiency, which indicates the mass of fuel needed to produce one unity of power in one unity of time. That result is in accordance with different authors who report that productivity of the skidder is more sensible to the distance of extraction, however, being also dependent on the slope of the ground, load dragged, traffic conditions and type of wheels.

Considering the average fuel consumption of the skidder equal to 20 liters per hour, independently from the type of wheels mounted, the specific fuel consumption was observed as $110.42 \mathrm{~g}$ $\mathrm{Kw} \mathrm{h}{ }^{-1}$ resulting in an average energy efficiency of $1.81 ; 2.06$ and $2.08 \mathrm{~g} . \mathrm{kW}^{-1} \mathrm{~m}^{3} \mathrm{cc}$ for the treatments SDP, SD2 and SD4.

Analyzing the different types of wheels it was verified that, in the shorter distances of extraction, there was no significant difference in productivity and energy efficiency of the skidder. However with the increase of the Distance of Extraction (above $100 \mathrm{mt}$.) it is observable a significant difference in the productivity of the SPD $\left(52,1 \mathrm{~m}^{3} \mathrm{he}^{-1}\right)$ when compared to SD4 $\left(35,5 \mathrm{~m}^{3} \mathrm{he}^{-1}\right)$ and SD2 $\left(37,1 \mathrm{~m}^{3} \mathrm{he}^{-1}\right)$. This is due to the higher mobility and operative speed of the machine with rubber tires in these conditions, allowing the reduction of loaded and unloaded trip times, with consequent increase of productivity and reduction of production costs.

Table 1. Average productivity and energy consumption of skidder with different wheel types and extraction distances.

Tabela 1. Produtividade e rendimento energético médio do skidder com diferentes tipos de rodados e distâncias de extração.

\begin{tabular}{|c|c|c|c|c|c|c|}
\hline \multirow{3}{*}{$\begin{array}{l}\text { Distance of } \\
\text { Extraction (m) }\end{array}$} & \multicolumn{6}{|c|}{ Type of wheels } \\
\hline & SD4 & SD2 & SDP & SD4 & SD2 & SDP \\
\hline & \multicolumn{3}{|c|}{ Productivity $\left(\mathrm{m}^{3} \mathrm{he}^{-1}\right)$} & \multicolumn{3}{|c|}{ Energy efficiency $\left(\mathrm{g} \mathrm{kW}^{-1} \mathrm{~m}^{3}\right)$} \\
\hline $\mathrm{DE}<50$ & $79,51 \mathrm{Aa}$ & $79,28 \mathrm{Aa}$ & $79,39 \mathrm{Aa}$ & $1,39 \mathrm{Aa}$ & $1,39 \mathrm{Aa}$ & $1,39 \mathrm{Aa}$ \\
\hline $50 \leq \mathrm{DE}<100$ & $63,22 \mathrm{Ba}$ & $61,04 \mathrm{Ba}$ & $56,94 \mathrm{Bb}$ & $1,75 \mathrm{Ba}$ & $1,81 \mathrm{Ba}$ & $1,93 \mathrm{Ba}$ \\
\hline $100 \leq \mathrm{DE}<150$ & $35,48 \mathrm{Ca}$ & $37,07 \mathrm{Ca}$ & $52,11 \mathrm{Bb}$ & $3,11 \mathrm{Ca}$ & $2,98 \mathrm{Ca}$ & $2,12 \mathrm{Bb}$ \\
\hline Means & 59,40 & 59,13 & 62,81 & 2,08 & 2,06 & 1,81 \\
\hline
\end{tabular}

Means followed by the same lower case letter in the line and upper case letter in the column are not different between them by the

Tukey range test at $5 \%$ of significance.

\section{Operational and production costs}

Considering an interest tax of $12 \%$ per year, $80 \%$ depreciation and $10 \%$ administrative costs, the total average operational cost per effectively worked hour resulted $\mathrm{R} \$ 195.00 ; \mathrm{R} \$ 182.28$ e $\mathrm{R} \$ 169.56$ respectively for SDP, SD2 and SD4. The lower operational cost of SD4 may be due to the fact that during the operative life of the machine there is no need to calculate the substitution of the rubber tires, because when tracks are correctly installed, they have the tendency to better protect the rubber wheels, avoiding premature wear, even if the initial cost for the acquisition of the tracks is considered. 
Figure 3 shows the contribution to the operational cost of the skidder generated by the the percentage of each component, with the different types of wheels. As it can be noticed, within the fixed costs, depreciation represent the higher percentage of the total costs, with $10,1 \%, 15,3 \%$ and $21,3 \%$ respectively for SDP, SD2 and SD4, due to the cost for the acquisition of tracks, mainly in the machine with all the four wheels equipped with tracks. Despite this, SD4 presented a lower total operational cost, due to the fact that substitution of the the rubber wheels is not needed over the operational life of the machine, as per the indications of the producer and of the forest company.

Proceeding with the analysis of the variable costs, it is verified a great contribution of the fuel consumption to the total operational cost, being very evident in SD4 with 31.5\%, followed by SD2 and SDP respectively with $29.1 \%$ and $27 \%$ of the total cost.
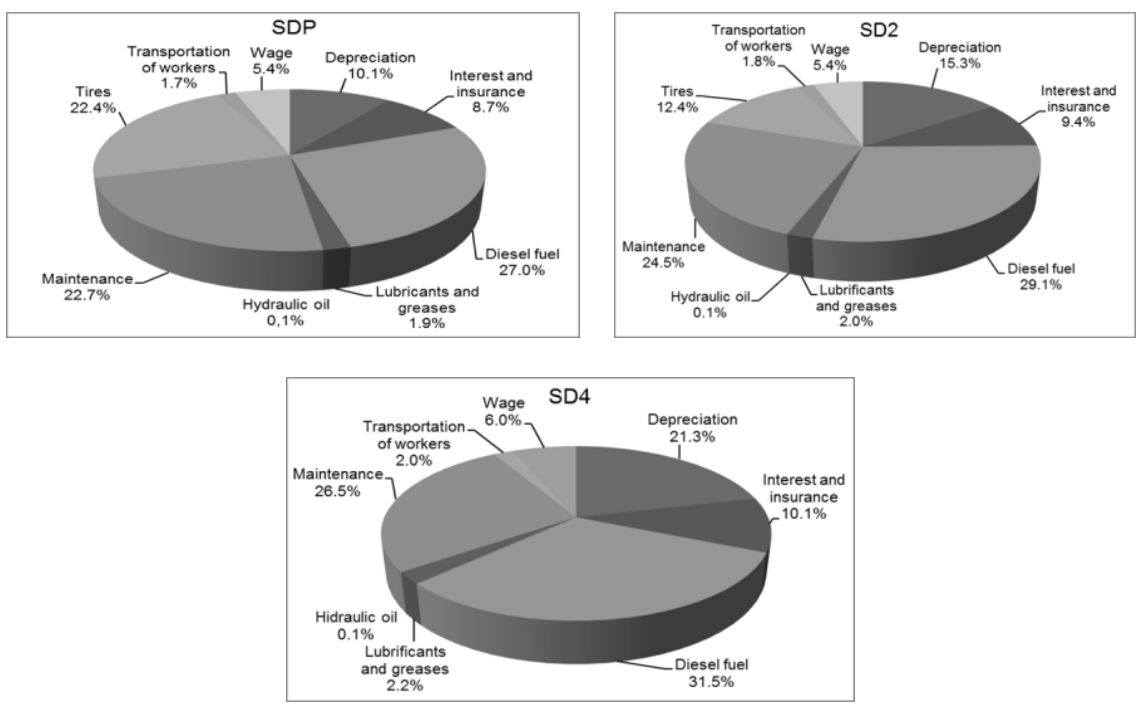

Figure 3. Components of the operating cost in percentage for the skidder with different wheel types.

Figura 3. Componentes do custo operacional percentual do skidder com diferentes tipos de rodados.

Table 2 presents the mean values of production cost of the skidder equipped with different type of wheels. In all the studied situations, production cost increased proportionally to the increase of the distance of extraction, due to the longer operational cycle time and to the lower productivity of the machine under those conditions.

Table 2. Average production cost of the skidder with different types of wheels and extraction distances. Tabela 2. Custo de produção médio do skidder com diferentes tipos de rodados e distâncias de extração.

\begin{tabular}{lccc}
\hline \multirow{2}{*}{ Distance of extraction (m) } & \multicolumn{3}{c}{ Production cost $\left(\mathbf{R} \mathbf{\$} \mathbf{~ m}^{-\mathbf{3}}\right)$} \\
\cline { 2 - 4 } $\mathrm{DE}<50$ & $\mathbf{S D 4}$ & $\mathbf{S D 2}$ & SDP \\
$50 \leq \mathrm{DE}<100$ & $2,13 \mathrm{Aa}$ & $2,30 \mathrm{Aa}$ & $2,46 \mathrm{Ab}$ \\
$100 \leq \mathrm{DE}<150$ & $2,68 \mathrm{Ba}$ & $2,99 \mathrm{Ba}$ & $3,42 \mathrm{Ba}$ \\
\hline Means & $4,78 \mathrm{Ca}$ & $4,92 \mathrm{Ca}$ & $3,74 \mathrm{Bb}$ \\
\hline
\end{tabular}

Means followed by the same lowercase letter in the line and by the same uppercase letter in the column are not different between them by the Tukey range test at $5 \%$ of significance.

Analyzing the production cost for each distance of extraction, it was verified that there was no significant difference between the different types of wheels, with the exception of the machine with rubber tires and an extraction distance above $100 \mathrm{~m}$, which presented an average production cost of $\mathrm{R} \$$ $3,74 \mathrm{~m}^{-3}$, which can be due to the higher operating speed developed by the machine when equipped with rubber wheels during the extraction operation. 


\section{Estimated productivity of the skidder with different wheels}

Analyzing the models to estimate productivity (PROD), it is noticed that in all the equations, the variables volume and distance of extraction contributed in the pure form, except for SDP (Table 3). The best adjustment was obtained for the SD2 configuration, while the model with the "dummy" variable had an intermediate adjustment.

Table 3. Adjusted equations to estimate productivity of the skidder with different types of wheels.

Tabela 3. Equações ajustadas para estimativa da produtividade do skidder com diferentes tipos de rodados.

\begin{tabular}{|c|c|c|c|c|c|c|}
\hline $\begin{array}{l}\text { Type of } \\
\text { wheels }\end{array}$ & Model & Equations & $R 2$ aj & Syx & $\begin{array}{l}\text { Syx } \\
(\%)\end{array}$ & $\begin{array}{c}\text { Value } \\
\mathbf{F} \\
\end{array}$ \\
\hline SD4 & MRMS & $\mathrm{PROD}=46.00 * *-0.52 * * \mathrm{DE}+12.11 * * \mathrm{VOL}$ & 0.52 & 24.6 & 33.8 & 182.4 \\
\hline SD2 & MRMS & $\mathrm{PROD}=51.30 * *-0.56 * * \mathrm{DE}+12.43 * * \mathrm{VOL}$ & 0.61 & 21.3 & 30.9 & 138.1 \\
\hline SDP & MRMS & $\begin{array}{c}\mathrm{PROD}=-7.91+73874.5 * * \mathrm{DE}-2+12.72 * * \mathrm{VOL} \\
\mathrm{PROD}=46.29 * *+0.71 * * \mathrm{ROD}(1)+3.56 * * \mathrm{ROD}(2)-\end{array}$ & 0.54 & 22.7 & 31.8 & 179.3 \\
\hline Todos & GLM & $\begin{array}{c}0.42 * * \mathrm{DE}+11.10^{* *} \mathrm{VOL} \\
\text { where: } \operatorname{ROD}(1)=1 \text { for SD2, }-1 \text { for SD4, } 0 \text { for SDP } \\
\operatorname{ROD}(2)=1 \text { for SDP, }-1 \text { for SD4, } 0 \text { for SD2 }\end{array}$ & 0.54 & 20.6 & 28.8 & 241.8 \\
\hline
\end{tabular}

*significant at 5\%; **significant at 1\%; $\mathrm{R}^{2}$ aj: adjusted coefficient of determination; Syx: standard error of the estimate in $\mathrm{m}^{3} \mathrm{he}^{-1}$. MRMS: Multiple Regression Model by Stepwise; GLM: Generalized Linear Regression Model (GLM); PROD: Productivity with each type of wheels; DE: Distance of Extraction; VOL: Volume Extracted per Operative Cycle (VOL) and ROD: Type of Wheels.

For the skidder with tracks on the four wheels, the estimated values out of MRMS and GLM did not differ from the observed values, following the same tendency (Table 4). However, for SD2 and SDP, only the values estimated with MRMS did not differ from what observed in the field, because it was found difference between the values estimated with GLM and the observed values in the class of the longest distance of extraction. Furthermore, for SDP, the GLM values did not follow the same tendency. This shows that a generalized model, although is more practical, is not recommended to estimate the productivity of a skidder in the different conditions of wheels and long distances of extraction.

Table 4. Observed and estimated productivity with the adjusted models for the skidder with different types of wheels and extraction distances.

Tabela 4. Produtividade observada e estimada pelos modelos ajustados para o skidder com diferentes tipos de rodados e distâncias de extração.

\begin{tabular}{|c|c|c|c|}
\hline \multirow{2}{*}{ Distance of extraction (m) } & \multicolumn{3}{|c|}{ Productivity $\left(\mathrm{m}^{3} \mathrm{he}^{-1}\right)$} \\
\hline & Observed & Estimated with MRMS & Estimated with GLM \\
\hline \multicolumn{4}{|c|}{ SD4 } \\
\hline $\mathrm{DE}<50$ & $79.51 \mathrm{Aa}$ & $80,02 \mathrm{Aa}$ & $75,73 \mathrm{Aa}$ \\
\hline $50 \leq \mathrm{DE}<100$ & $63.22 \mathrm{Ba}$ & $63,43 \mathrm{Ba}$ & $63,04 \mathrm{Ba}$ \\
\hline $100 \leq \mathrm{DE}<150$ & $35.48 \mathrm{Ca}$ & $43,15 \mathrm{Ca}$ & $46,97 \mathrm{Ca}$ \\
\hline Mean & 59.40 & 62.20 & 61.91 \\
\hline \multicolumn{4}{|c|}{$\mathrm{SD} 2$} \\
\hline $\mathrm{DE}<50$ & $79.28 \mathrm{Aa}$ & $79.48 \mathrm{Aa}$ & $76.10 \mathrm{Aa}$ \\
\hline $50 \leq \mathrm{DE}<100$ & $61.04 \mathrm{Ba}$ & $60.88 \mathrm{Ba}$ & $63.40 \mathrm{Ba}$ \\
\hline $100 \leq \mathrm{DE}<150$ & $37.07 \mathrm{Cb}$ & $42.44 \mathrm{Cb}$ & $50.84 \mathrm{Ca}$ \\
\hline Mean & 59.13 & 60.93 & 63.45 \\
\hline \multicolumn{4}{|c|}{ SDP } \\
\hline $\mathrm{DE}<50$ & $79.39 \mathrm{Aa}$ & $76.82 \mathrm{Aa}$ & $76.83 \mathrm{Aa}$ \\
\hline $50 \leq \mathrm{DE}<100$ & $56.94 \mathrm{Ba}$ & $56.12 \mathrm{Ba}$ & $56.91 \mathrm{Ba}$ \\
\hline $100 \leq \mathrm{DE}<150$ & $52.11 \mathrm{Ba}$ & $54.63 \mathrm{Ba}$ & $38.00 \mathrm{Cb}$ \\
\hline Mean & 63.21 & 62.52 & 57.25 \\
\hline
\end{tabular}

Means followed by the same lowercase letter in the line and uppercase in the column are not statistically different between them by the Tuckey range test at 5\% of significance. MRMS: Multiple Regression Model by Stepwise and GLM: Generalized Linear Regression Model (GLM). 


\section{CONCLUSIONS}

Basing on the analysis and discussion the following conclusions were reached:

- The long time consumed by the skidder to execute additional maneuvers in the wood bundles loading operation caused an increase of the operative cycle time and loss of productivity, showing the need for an improvement of the operational planning.

- Productivity of the skidder with rubber tires was higher in the longest distances of extraction, resulting form the higher mobility of the machine with this type of wheels when compared to the ones equipped with tracks.

- Productivity and operational cost of the skidder equipped with tracks only on the front wheels were similar to the ones obtained by the machine with rubber tires, showing the potential for this being a technical and economical solution to conduct the extraction operation in the shorter distances and with the simultaneous presence of slopes and humid soils with low support capability.

- Productivity values of the observed machines and the estimated values with the adjusted models showed significant differences between them only in the longest distances of extraction, therefore the use of those models is not recommended under the described conditions.

\section{REFERENCES}

BARNES, R. M. Estudo de tempos e movimentos: projeto e medida do trabalho. São Paulo: Edgard Blucher, 1977, $635 \mathrm{p}$.

BRAMUCCI, M.; SEIXAS, F. Determinação e quantificação de fatores de influência sobre a produtividade de "harvesters" na colheita florestal. Scientia Forestalis, Piracicaba, n. 62, p. 62 - 74, 2002.

BYGDÉN, G.; WASTERLUND, I.; ELIASSON, L. Rutting and soil disturbance minimized by planning and using bogie tracks. In: SIMPÓSIO BRASILEIRO SOBRE COLHEITA E TRANSPORTE FLORESTAL, 6., 2003, Belo Horizonte. Anais... Belo Horizonte: Universidade Federal de Viçosa/Sociedade de Investigação Florestal, 2003. p. 1 - 9.

CONAW, P. L. Estatística. São Paulo: Edgard Blucher, 1977. 264 p.

EMPRESA BRASILEIRA DE PESQUISA AGROPECUÁRIA (EMBRAPA). Manual de métodos de análise de solo. 2.ed. Rio de Janeiro, 1997. 212 p.

FERNANDES, H. C.; LOPES, S. E.; TEIXEIRA, M. M.; MINETTE, L. J.; RINALDI, C. N.; BERNARDES, A. M. Avaliação das características técnica e econômica de um sistema de colheita florestal de árvores inteiras. Scientia Forestalis, Piracicaba, v. 37, n. 83, p. 225 - 232, 2009.

HENDRISON, J. Damage-Controlled Logging in Managed Tropical Rain Forest in Suriname. The Netherlands: Agricultural University Wageningen. 1990. p. 62 - 138.

LOPES, E. S. Aplicação do programa SNAP III (Scheduling and Network Analysis Program) no planejamento da colheita e do transporte florestal. $150 \mathrm{f}$. Tese (Doutorado em Ciência Florestal), Universidade Federal de Viçosa, Viçosa, 2001.

LOPES, E. S.; MISSEL, J. W. P.; DIAS, A. N.; FIEDLER, N. C. Avaliação técnica do trator florestal arrastador skidder com diferentes tipos de rodados na extração de madeira em povoamentos de pinus. Revista Árvore, Viçosa, v. 31, n. 6, p. 1053 - 1061, 2007.

LOPES, E. S.; SAMPIETRO, J. A.; PEREIRA, A. L. N.; OLIVEIRA, D. Compactação de um latossolo submetido ao tráfego de Skidder com diferentes rodados. Floresta, Curitiba, v. 41, n. 3, p. 471 - 480, 2011.

MACHADO, C. C. Exploração florestal, 6. Viçosa, MG, Imprensa Universitária, UFV, 1989. 34 p.

MACHADO, C. C. Colheita Florestal. 2a ed. Viçosa, MG, Editora UFV, 2008. 501 p. 
MINETTE, L. J.; MOREIRA, F. M. T.; SOUZA, A. P.; MACHADO, C. C.; SILVA, K. R. Análise técnica e econômica do forwarder em três subsistemas de colheita de florestas de eucalipto. Revista Árvore, Viçosa, v. 28, n. 1, p. 91 - 97, 2004.

MIYATA, E. S. Determining fixed and operating costs of logging equipment. (S.I.): Washington: USDA Forest Service, 1980. 16 p. (General Technical Report, NC-55).

OLIVEIRA, D.; LOPES, E. S.; FIEDLER, N. C. Avaliação técnica e econômica do forwarder na extração de toras de pinus. Scientia Forestalis, Piracicaba, v. 37, n. 84, p. 525 - 533, 2009.

SEIXAS, F. Extração florestal. In: MACHADO, C. C. Colheita florestal. 2. ed. Viçosa, MG, Editora UFV, 2008. p. 97 - 145.

WARKOTSCH, P. W.; OLSEN, G. F. Identification and quantification of soil compaction due to various harvesting methods. In: Council on Forest Engineering Annual Meeting. IUFRO, 17., 1992. Proceedings. Oregon: 1992. $16 \mathrm{p}$. 